\title{
Correction to: High dose simultaneous integrated boost for node positive cervical cancer
}

Iresha Jayatilakebanda', Yat Man Tsang ${ }^{1}$ and Peter Hoskin ${ }^{1,2^{*}}$

\section{Correction to: Radiat Oncol (2021) 16:92}

$$
\text { https://doi.org/10.1186/s13014-021-01818-1 }
$$

Following publication of the original article [1], the author identified an error in the author name of Iresha Jayatilakebanda.

- The incorrect author name is: Iresha Ayatilakebanda

- The correct author name is: Iresha Jayatilakebanda

The author group has been updated above and the original article [1] has been corrected.

\section{Author details}

${ }^{1}$ Mount Vernon Cancer Centre, Rickmansworth Road, Northwood, Middlesex HA6 2RN, UK. ${ }^{2}$ University of Manchester, Manchester, UK.

Published online: 18 August 2021

\author{
Reference \\ 1. Jayatilakebanda I, Tsang YM, Hoskin P. High dose simultaneous integrated \\ boost for node positive cervical cancer. Radiat Oncol. 2021;16:92. https:// \\ doi.org/10.1186/s13014-021-01818-1.
}

\section{Publisher's Note}

Springer Nature remains neutral with regard to jurisdictional claims in published maps and institutional affiliations. original author(s) and the source, provide a link to the Creative Commons licence, and indicate if changes were made. The images or other third party material in this article are included in the article's Creative Commons licence, unless indicated otherwise in a credit line to the material. If material is not included in the article's Creative Commons licence and your intended use is not permitted by statutory regulation or exceeds the permitted use, you will need to obtain permission directly from the copyright holder. To view a copy of this licence, visit http://creativecommons.org/licenses/by/4.0/. The Creative Commons Public Domain Dedication waiver (http://creativecommons.org/publicdomain/zero/1.0/) applies to the data made available in this article, unless otherwise stated in a credit line to the data. 